\title{
L命NTING
}

\section{GALLERI ARSITEKTUR BANJAR}

\author{
Febry Ramadan Saifudin \\ Program Studi Teknik Arsitektur Fakultas Teknik Universitas Lambung Mangkurat \\ Febryramadansaifudin@gmail.com \\ Ira Mentayani \\ Program Studi Teknik Arsitektur Fakultas Teknik Universitas Lambung Mangkurat \\ ira arch@ulm.ac.id
}

\begin{abstract}
ABSTRAK
Galeri Arsitektur Banjar merupakan salah satu dari solusi untuk menambah minat masyarakat kota Banjarmasin untuk mempelajari perkembangan kotanya sendiri. Inti yang dibutuhkan bagaimana rancangan bangunan dapat menjadi agen sosialisasi yang rekreatif dan edukatif agar membuat pengunjung memahami Arsitektur kota Banjarmasin. Pada akhirnya, Desain Galeri Arsitektur dapat terwujud sebagai bangunan bermassa tunggal dengan penyajian koleksi hologram rumah Banjar yang disajikan dari fungsi rumah, sejarah hirarki rumah, serta proses awal pembuatan rumah. Di lantai 1 menceritakan sejarah dan proses pembuatan rumah banjar. Lantai 2 iyalah tempak kita melakukan prose perakitan dengan teknologi hologram.
\end{abstract}

Kata kunci: kota Banjarmasin, Galeri Arsitektur, Rumah Banjar

\begin{abstract}
Banjar Architecture Gallery is one of the solutions to increase the interest of the people of Banjarmasin city for the benefit of developing their own city. The essence needed about building construction can be a creative and educative socialization agent to make visitors understand Banjarmasin city architecture. In the end, the Architectural Gallery Design can be realized as a single mass building by presenting a Banjar house holographic collection presented from the house, the history of the house's hierarchy, and the initial process of making a house. On the 1st floor tells the history and process of making banjarise house. The second floor is where we proceed with hologram technology.
\end{abstract}

Keywords: Banjarmasin city, Architecture Gallery, Banjar House

\section{LATAR BELAKANG}

Galeri merupakan tempat strategis berupa khusus yang memberikan informasi lengkap kepada masyarakat umum mengenai bentuk bangunan rumah Bangunan Tradisional Rumah Banjar yang ada, sangat biasa menjadi destinasi sarana pariwisata yang cukup banyaknya namun keadaan masyarakat sekarang kurang mengetahui apa saja jenis rumah- rumah tersebut. Dengan demikian pemerintah kota Banjarmasin memiliki rencana untuk membangun sebuah wadah yang bersifat menceritakan kota Banjarmasin.
Dengan melihat fenomena di atas, maka timbul gagasan untuk diperlukannya suatu wadah penyajian karya seni arsitektur banjar. yang bertujuan untuk memudahkan mahasiswa Arsitektur, para dosen dan masyarakat yang ingin belajar serta mendapat informasi seputar Arsitektur Banjar yang lebih mendalam. Tujuan lain adalah mengembalikan citra bangunan berkarakter budaya banjar melalui bangunan Galeri Arsitektur. Galeri yang memiliki ruang-ruang pameran yang menyimpan, menjual dan memamerkan koleksi khusus hasil Arsitektur banjar yang telah terseleksi dengan nilai seni dan budaya. 


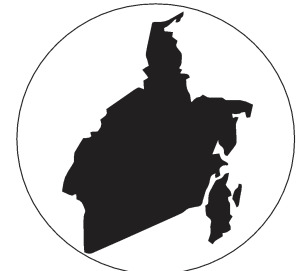

BANJARMASIN Memiliki sejarah kota.

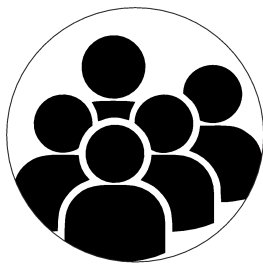

Kurangnya pengetahuan terhadap kebudayaan sendiri.

masyarakat

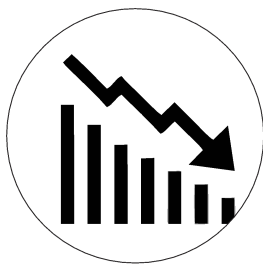

Kurangnya even-even yang berkaitan dengan bangunan Banjar.

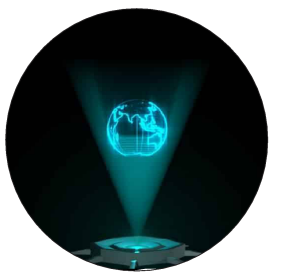

Kurangnya fasilitas modern di Banjarmasin.

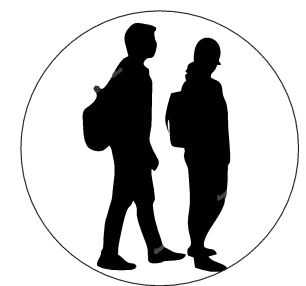

Meningkatnya wisatawan luar daerah

\section{PERMASALAHAN}

Berdasarkan latar belakang yang diterangkan di atas, maka permasalahan arsitektural untuk Galeri Arsitektur Banjar Bagaimana merancang sebuah Galleri membuat masyarakat Banjarmasin dapat memahami bentuk rumah Banjar serta sejarah proses pembuatan rumah tradisional tersebut?

\section{TINJAUAN PUSTAKA}

\section{A. Tinjuan Gallery}

Galeri adalah tempat dapat pula diartikan sebagai tempat yang memamerkan karya seni tiga dimensi karya seorang atau sekelompok seniman atau bisa juga didefinisikan sebagai ruangan atau gedung tempat untuk memamerkan benda atau karya seni.

Dalam arsitektur, galeri adalah tempat untuk memamerkan karya seni. Dan galeri dapat pula dijadikan wadah kegiatan aktivitas komunitas di dalam suatu ruangan antara seniman dan masyarakat yang berkunjung melalui kegiatan pameran dan seminar.

Arsitektur adalah seni yang diciptakan setiap manusia mengimajinasikan dirinya dan ilmu mereka untuk merancang bangunan maka Dalam arti yang lebih luas, arsitektur iyalah merancang dan membangun keseluruhan lingkungan binaan, baik itu dari hal yang besar yaitu perencanaan kota sampai ke hal kecil seperti desain perabot dan produk,

Banjar adalah berasal dari kata Banjarmasin. Banjarmasin adalah nama suatu kampung di muara sungai kuin, sebuah anak sungai barito.

- Jenis- jenis rumah Banjar

Rumah Banjar ada terdapat 11 jenis yaitu: Rumah Bubungan tinggi (sebagai rumah raja), Rumah Gajah Baliku (sebagai rumah saudara- saudara sultan), Rumah Palimasan (sebagai rumah bendahara), Rumah Balai Bini ( sebagai rumah putri), Rumah Tadah Alas (pengembangan balai bini), Rumah Gajah Manyusu( sebagai warit raja), Rumah Balai Laki ( prajurit pengawal), Rumah Palimbangan( rumah tokoh agama), Rumah Cacak burung(rumah rakyat), Rumah Lanting(rumah apung),Rumah Joglo(sebagai rumah rakyat cina). 


\section{B. Tinjauan Konsep Bangunan}

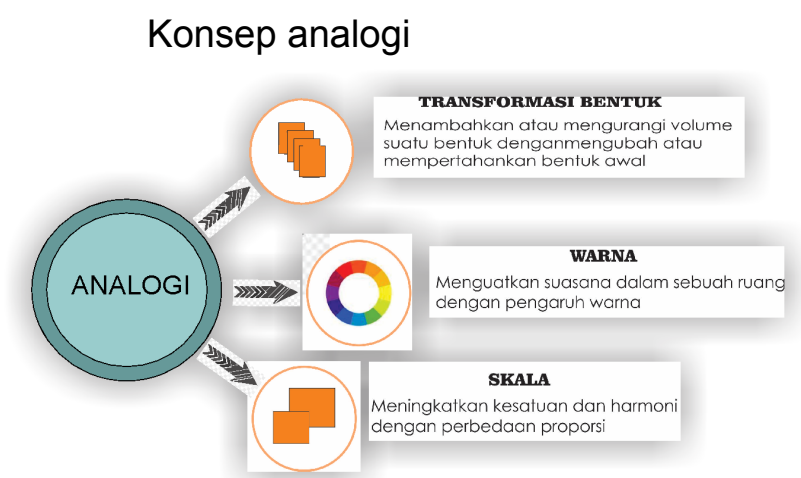

Gambar 1. Konsep analogi

Analogi diterapkan pada bentuk bangunan yang penyederhanaan bentukan rumah banjar yaitu bubungan tinggi. Yang paling menonjol iyalah bentuk bubungan rumah .

\section{METODE}

- Konsep learning by doing

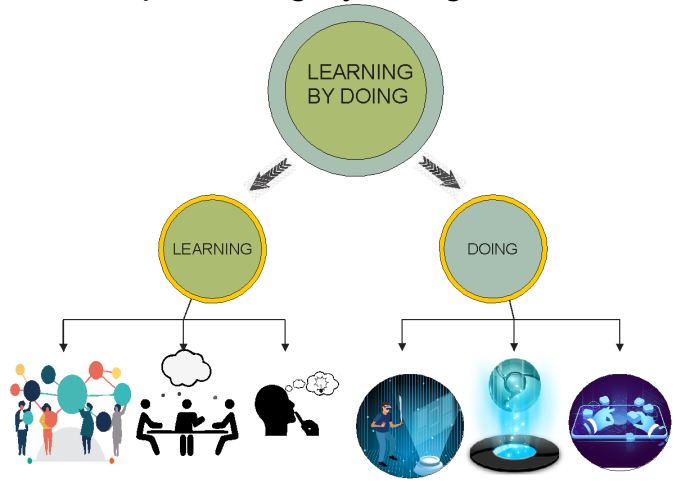

Gambar 2. Learning by doing

Metode learning by doing dimana proses learning iyalah pengunjung dapat belajar bagaimana awal mulai sejarah rumah banjar.sedangkan doing pengunjung dapat merangkai bangunan dengan teknologi hologram.

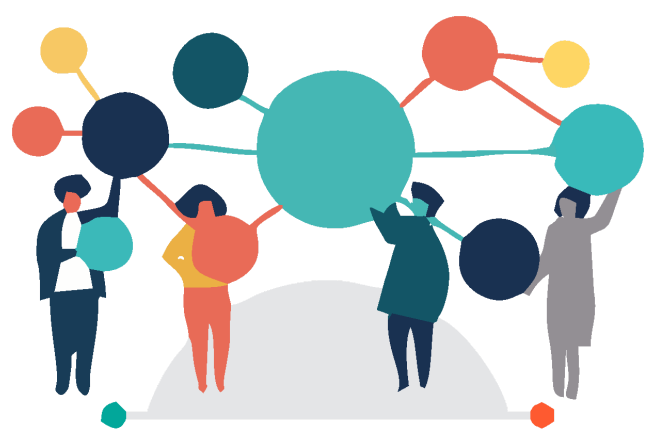

Gambar 3. Aktivitas pengunjun

Masyarakat dapat memilih jenis rumah yang ingin mereka pelajari.

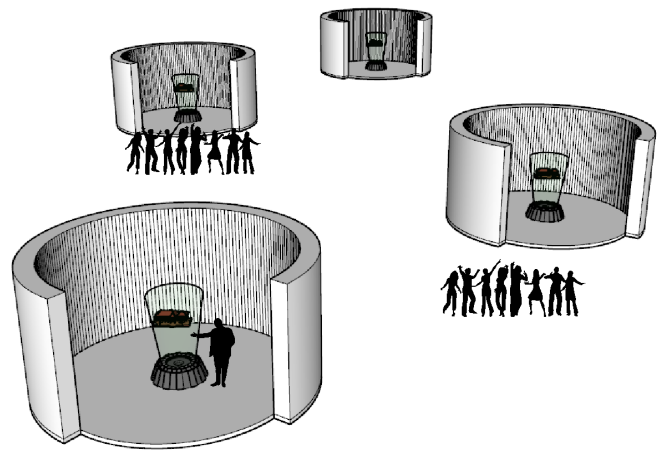

Setiap bilik menceritakan khusus satu jenis rumah yang disajikan dengan teknologi virtual dimana pengguna dapat melihat dengan rasa yang lebih nyata.

\section{PEMBAHASAN}

Bangunan ini sebagai wadah informasi bagi masyarakat kota banjarmasin ataupun pendatang yang bertujuan untuk mengedukasi masyarakat tentang kebudayaan banjar khususnya rumah tradisional. Masyarakat diarahkan dengan proses pembelajaran yang menarik, dimana masyarakat dapat melihat sejarah rumah tradisionalnya hingga proses pembuatannya. Konsep yang diterapkan pada ruang dalam iyalah learning by doing dimana pengunjung dapat belajar sambil berinteraksi langsung membuat bentukan rumah 
- Denah

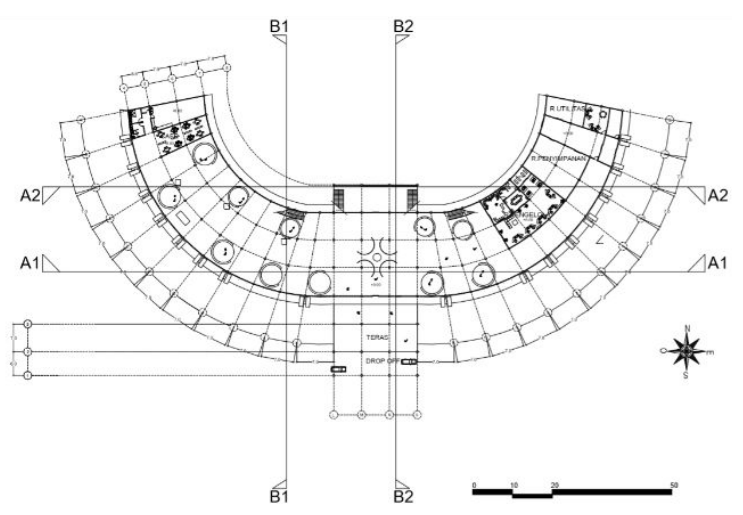

Gambar 4. Denah Lantai 1

Lantai 1 berfungsi sebagai tempat informasi dimana setiap bilik menceritakan bagaimana sejarah,fungsi rumah tersebut.

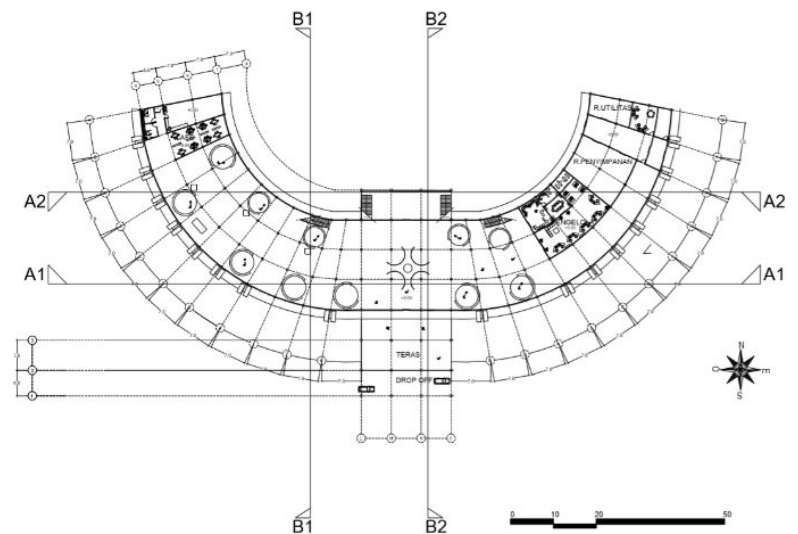

\section{Gambar 5. Denah Lantai 2}

Lantai 2 berfungsi sebagai tempat membuat rumah dengan teknologi hologram.

- Tampak

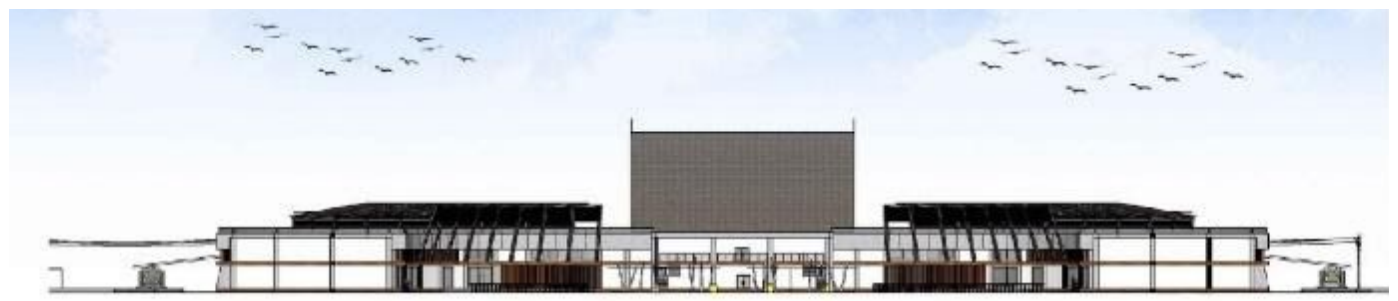

Gambar 6. Tampak depan

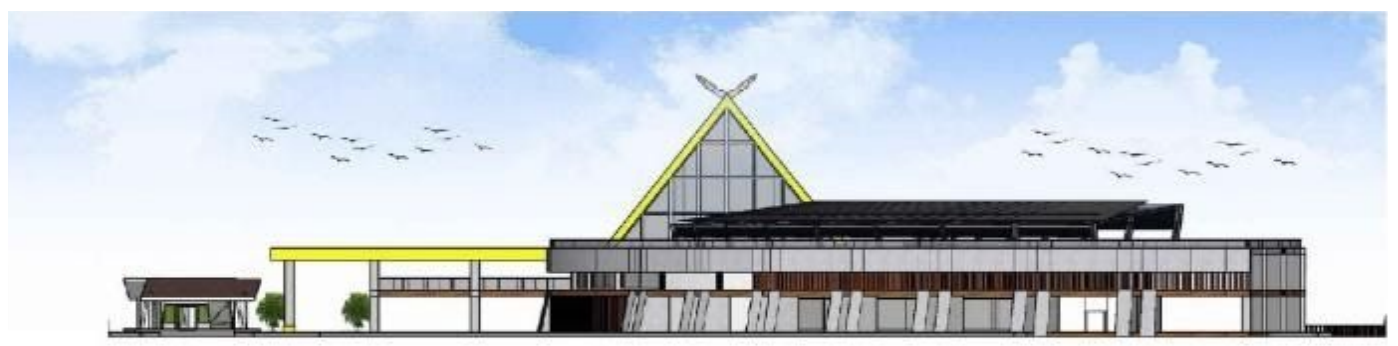

Gambar 7. Tampak samping

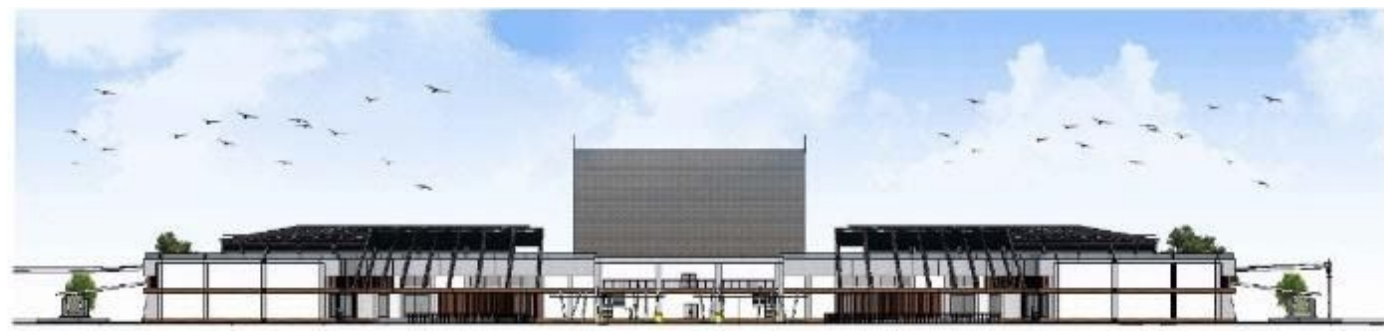

Gambar 8. Tampak belakang 
- Potongan

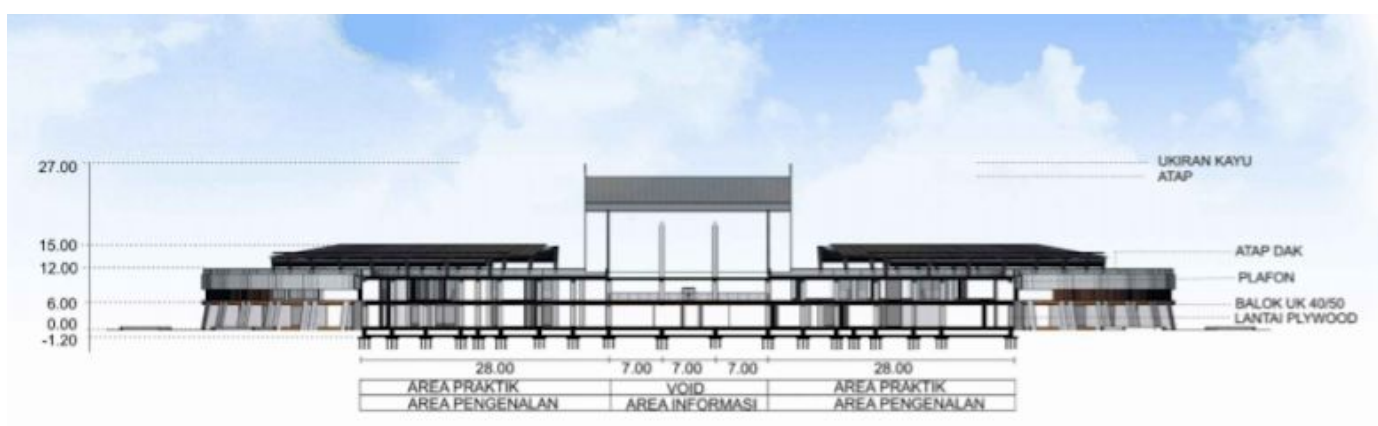

Gambar 9. Potongan A1-A1

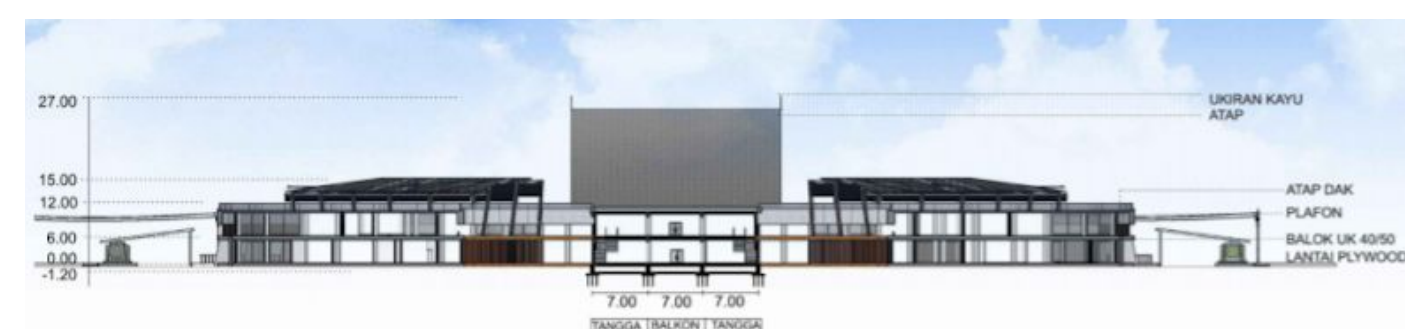

Gambar 10. Potongan A2-A2

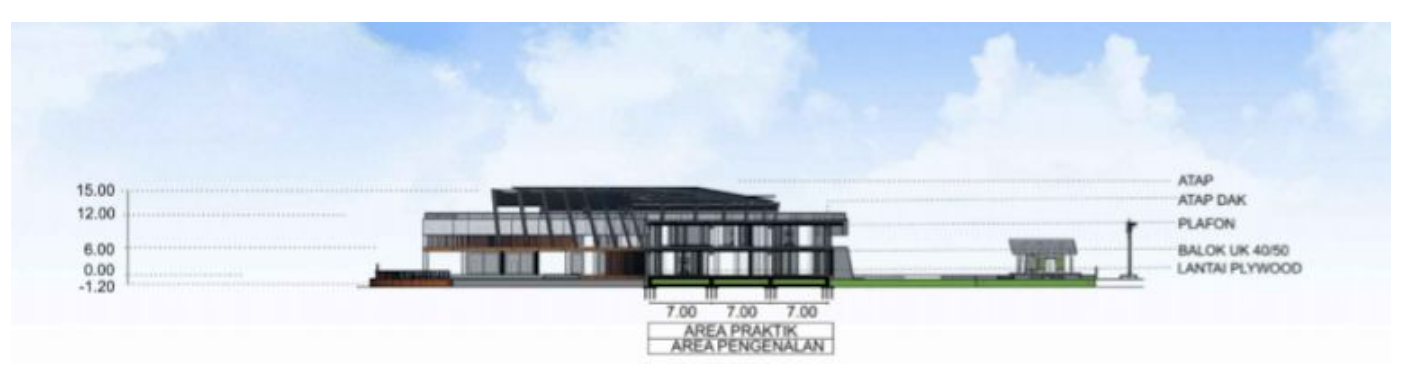

Gambar 11 Potongan B1-B1

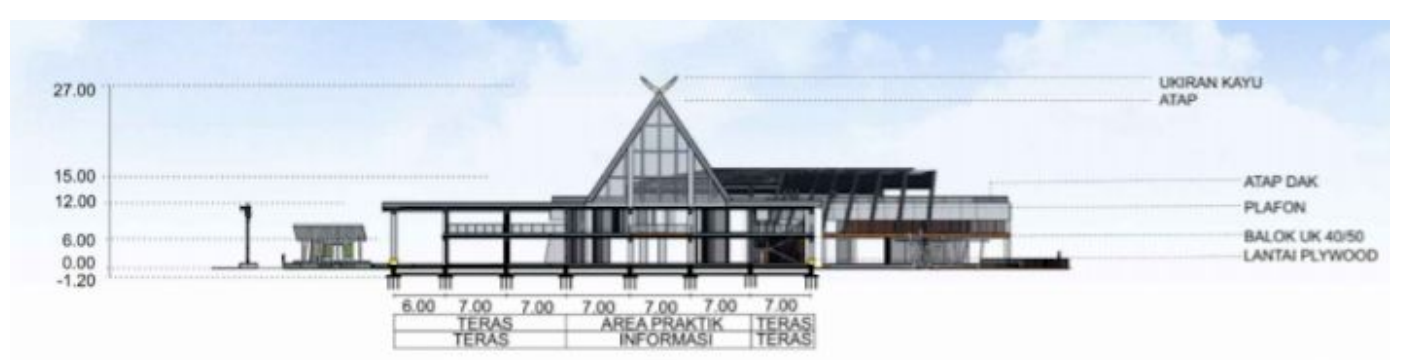

Gambar 11 Potongan B2-B2 


\section{PENERAPAN KONSEP RANCANGAN}

\section{A. Konsep Interior}

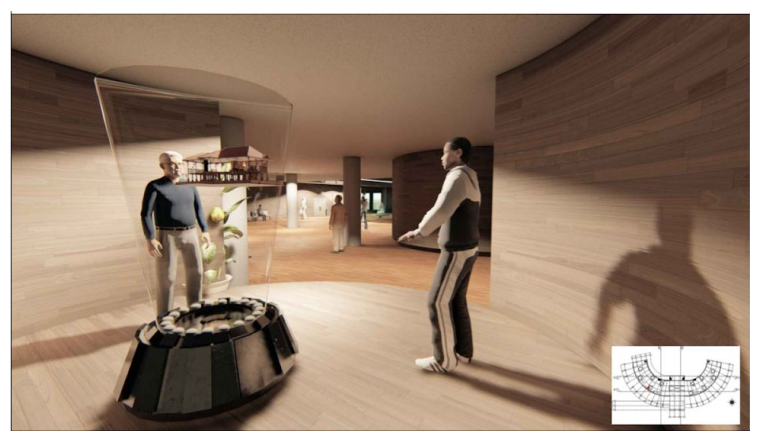

Gambar 12. Interior 1

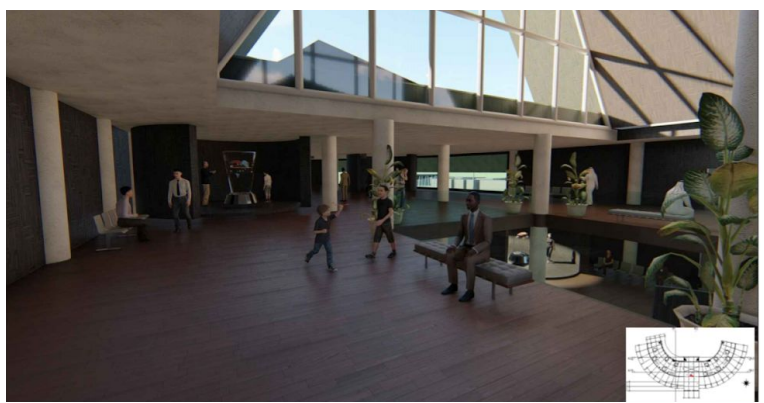

Gambar 13. Interior 2

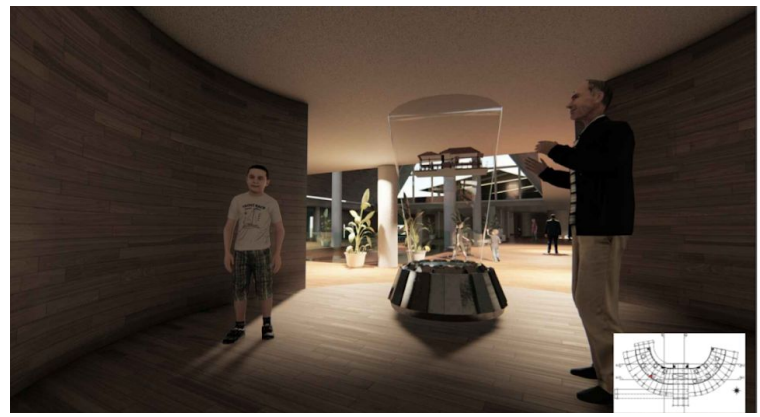

Gambar 14. Interior 3

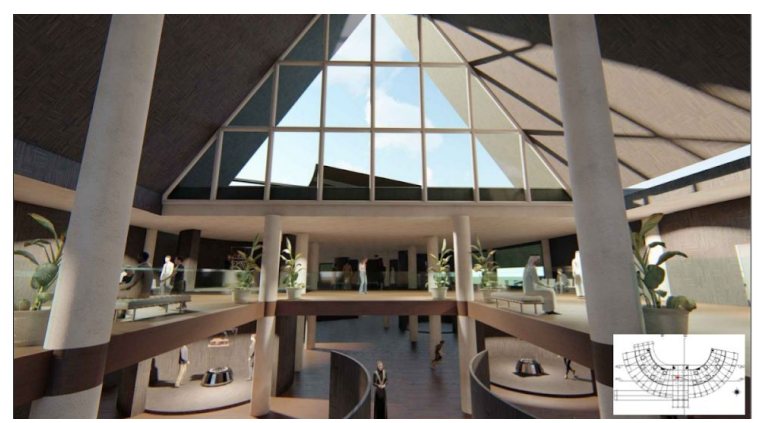

Gambar 15. Interior 4

Interior bangunan memiliki bilik-bilik khusus yang setiap biliknya menceritakan satu macam bangunan rumah tradisional banjar dengan fasilitas hologram masyarakat lebih antusias dalam pembelajaran dan melakukan praktek.

\section{B. Konsep Eksterior}

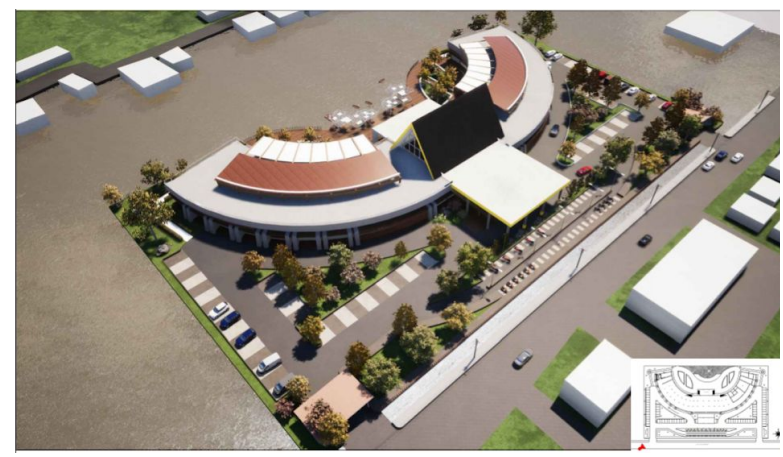

\section{Gambar 16. Eksterior 1}

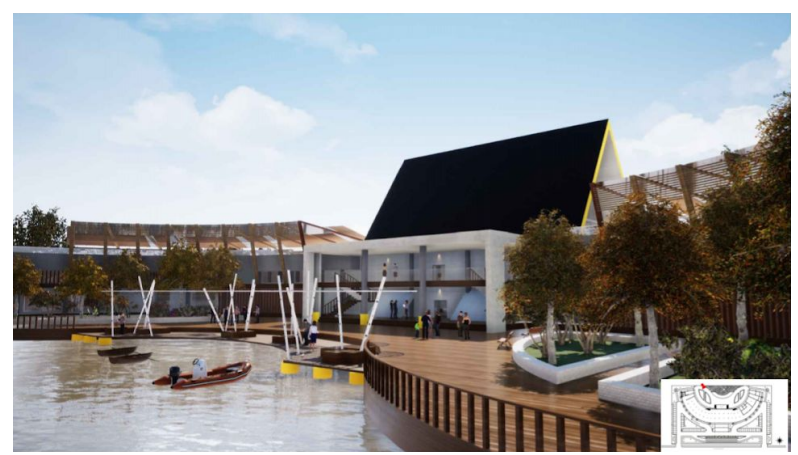

\section{Gambar 17. Eksterior 2}

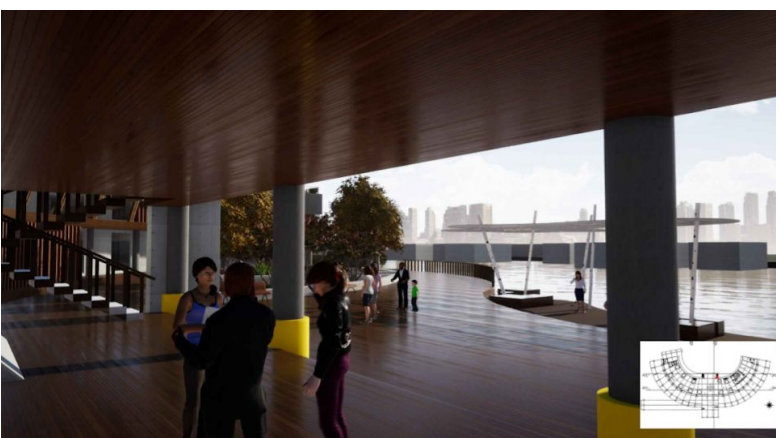

Gambar 18. Eksterior 3

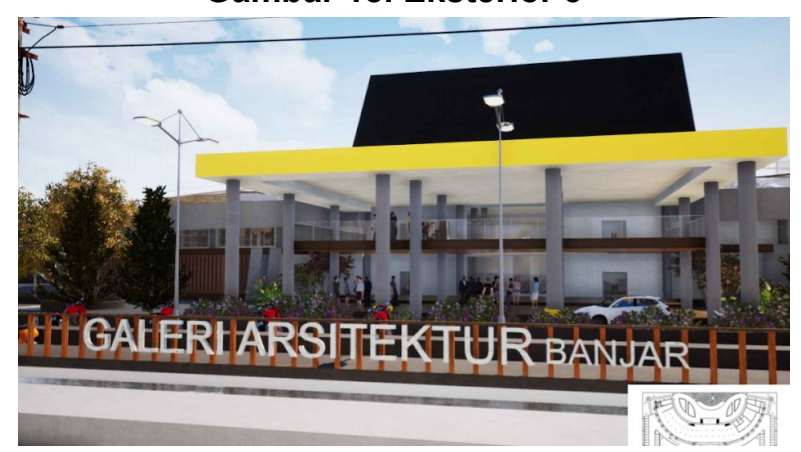

Gambar 19. Eksterior 4 


\section{DAFTAR PUSTAKA}

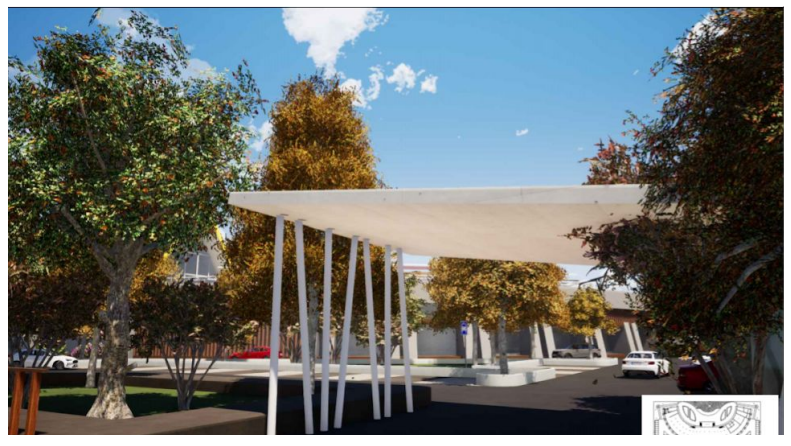

Gambar 20. Eksterior 5

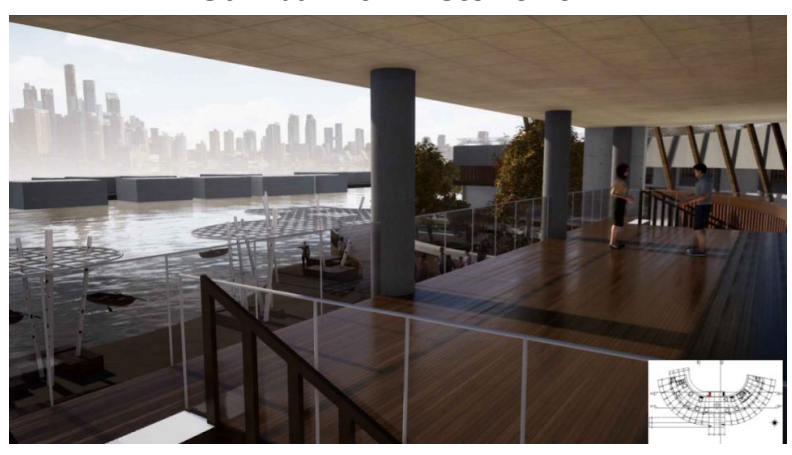

Gambar 21. Eksterior 6

Eksterior bangunan site yang berada di pinggir sungai menimbulkan kesan kotabanjarmasin yang dikenal dengan kota 1000 sungai.sesuai dengan aturan kota Banjarmasin bangunan harus bersifat 2 akses yaitu darat dan sungai dimana area belakang bias dijadikan tempat berkumpul dan area pembelajaran.

\section{KESIMPULAN}

Galeri Arsitektur Banjar di Banjarmasin bertujuan untuk mengedukasi masyarakat tentang bentuk rumah Banjar

Metode penyelesaian masalah yang digunakan dalam perancangan Galeri arsitektur Banjar adalah Learning by doing, yaitu dengan masyarakat dapat melakukan aktivitas langsung dengan teknologi vitral yang lebih menarik di era sekarang .

Galleri ini diharapkan dapat menjadi sarana edukasi dan pariwisata kota Banjarmasin dari sisi bangunan tradisional rumah Banjar.
Barliana, Syaom. (2001). Pengantar Arsitektur. Bandung: Universitas Pendidikan Indonesia.

Buxton, P. (2015). Metric Handbook (Planning and Design Data) 5th Edition. London and New York: Routledge

(Dictionary of Architecture and Construction, 2005).

Encyclopedia of American Architecture (1975) 